\title{
Aikuiskasvatus arvojen mosaiikissa mikä on jatkuvuuden voima?
}

\section{Maailma muuttuu - muuttuuko aikuiskoulutus? toim. Irene Hein \& Riitta Larna. Opetus 2000 WSOY 1994. $130 \mathrm{~s}$.}

Kansalais- ja työväenopisto 'en liiton, Aikuiskoulutuksen maailman ja WSOY:n yhdessä järjestämien Aikuisopettajapäivien kongressikirja tarkastelee muutosta, jonka aikuiskoulutuksen parissa työskentelevät ihmiset kokevat konkreettisesti omassa työssään sekä niissä vaatimuksissa, joita asiakkaat heille asettavat. Näkökulmina ovat tulevaisuuden tutkimus, työelämän muutos, kulttuuri, etäopetus ja etätyö, muutos oppijan kannalta, verkostuminen ja yhteistyö. Asiantuntija-artikkeleita ryydittävät Esa Saarisen ja Mark C. Taylorin ajatukset, jotka on sijoitettu teokseen eräänlaiseksi kuvitukseksi, joka luo kirjalle postmodernia ilmettä ja kannustaa oivalluksiin ja pohdintaan. Ensivaikutelma on sekava, mutta jos jaksaa lukea mitä on kirjoitettu, niin sisältö alkaa hahmottua.

Mika Mannermaa käsittelee tulevaisuudentutkimuksen luonnetta ja tehtävää sekä todennäköisen tulevaisuuden aiheuttamia haasteita aikuiskoulutukselle. Yhteiskunnallinen kehitys on Mannermaan mukaan parhaiten luonnehdittavissa vakaiden vaiheiden ja ennalta arvaamattomien murrosten välisenä vuorotteluna. Kaaos voi olla kvanttihyppy kehityksessä ja kehityksen edellytys: vanhan kuolema, jotta uutta voisi syntyä. Mannermaan mielestä olemme yhä selvemmin keskellä arvomurrosta kansallisen kasvun maailmasta johonkin uuteen. Koko konsensuskorporaatio on hänen mukaansa menneen tai ainakin parhaillaan väistyvän maailman jäänne, jonka ote on jo kirvonnut palautumattomasti. Ay-liike, vuorineuvokset, hallitus ja Suomen pankki eivät enää operoi tehokkaasti komentokeskuksessa, josta Suomi-laivaa on tavattu ohjata.

Mannermaan tuleva maailma näyttää olevan erilaisten yhdys- ja yhteiskuntien arvojen, elämäntapojen, uskontojen ja kulttuurien mosaiikki, jonka muutosilmiöissä keskeisiksi nousevat kysymys ekologisesti kestävästä kehityksestä ja teollisen tavarayhteiskunnan muuttuminen globalisoituvaksi tietointensiiviseksi vuorovaikutusyhteiskunnaksi. Kaaoksesta selvitään laaja-alaisella osaamisella ja sivistyksellä, jossa sivistyksellä on tietämisen, osaamisen, empatian ja solidaarisuuden ulottuvuudet. Määrästä laatuun siirryttäessä tieto nousee yhä keskeisemmäksi. Osaamisvaatimus on kasvussa yhtä hyvin tietointensiivisellä kuin ihmissuhteiden ja fyysisen osaamisen alueella. Ihmisenä olemisen pätevyysvaatimukset kasvavat. Keskeisin alue on oppinfiskyky. Ihmisenä olemisen sietokyvyssä, ekologisuudessa, ihmissuhteissa, eettisyydessä (arvoosaaminen, ideologiat, uskonnot) ja esteettisyydessä. Homo Sovjeticus -projekti ei onnistunut, mutta onko nyt tulossa uusi ihminen, Homo Intelligens?

Pauli Juuti käsittelee työeläman muutosta suurelta osin organisaatiokulttuurin muutoksen näkökulmasta. Hän esittelee mielenkiintoisella tavalla psykologista organisaatiotutkimusta ja päätyy ajatukseen, että uudenlaisen organisaatioajattelun perushahmo alkaa olla määräytynyt. Uudelle ajattelulle on tyypillistä joustavuus, tiimien ja monitoimisuuden käyttö, vaikuttavuus ja korkea laatu. Uudenlaiset organisaatiot ovat oppimispainotteisia. Entisen organisaatiokulttuurin korvaaminen uudella ei ole aivan yksinkertaista, koska se edellyttää kulttuurin syvärakenteen muutosta. Organisaatiolla on alitajuntainen perustarina, joka olisi korvattava uudella. Uusi perustarina mahdollistaisi aikuismaisen ja itseohjautuvan työskentelyn mikä edellyttää ihmisten sivistystason nousua ja persoonallisuuden kypsymistä.

Seppo Niemelä kirjoittaa kulttuurista tyylikkäästi ja syvämielisesti. Kulttuuri on hänelle kaikkea sitä, minkä ihminen on tehnyt ja joka ei ole olemassa luonnostaan. Kulttuuri on ihmiselle jotakin, jota ilman häntä ei ole olemassa, hän ei ole ilman sitä edes eläin. Tästä avautuu myös kulttuurin ja talouden välinen suhde. On väitetty, ettei kulttuuria ole ilman vahvaa taloutta. Kulttuuri tulee kuitenkin ennen talouselämää. Terve talous voi Niemelän mielestä toimia vain kulttuurin varassa. Inhimillinen pääoma on tärkeämpi kuin perinteiset tuotannontekijät. 
Niemelä tunnistaa kulttuurisia vahvuuksiamme ja heikkouksiamme. Olemme lyhyellä pikakurssilla koulutettu sivistyskansa, joka on lähellä juuriaan, pohjoisen havumetsävyöhykkeen alkuperäiskulttuuria. Olemme onnistuneet jalostamaan primitiivistä perintöämme hienostuneena selkeytenä ja yksinkertaisuutena arkkitehtuurissa ja muotoilussa. Silti olemme usein esteettisesti hukassa. Musiikillisesti olemme maailmanluokkaa; suuri merkitys on ollut myös laajalla teatteriharrastuksella. Taidekasvatuksemme kaipaisi kohennusta, se on portti henkiseen maailmaan ja täydentää tietopainotteisen opetuksen puisevaa yksipuolisuutta.

Niemelää askarruttaa selviytymisemme edessä olevassa eurooppalaisessa integraatiossa ja globaalien näkymien edessä. Vahva valtio on murtunut. Olemme ankaran kilpailun markkinoilla ilman valtion suojaa. joudumme avautumaan myös globaaleihin näkökulmiin. Kansakunta elää ulko- ja kulttuuripolitiikkansa varassa! Näistä lähtökohdista Niemelä hahmottelee aikuiskasvatusohjelmaansa, jossa vapaalla sivistystyöllä on tärkeä rooli.

Marjatta Rahikainen käsittelee kiinnostavasti ja jotenkin sapekkaasti etäopetusta ja etätyötä kustannustietoisina kaksosina. Hän panee tuotannon ja aikuiskoulutuksen historiallisesti limittäin ja löytää aikuiskoulutuksen kehittämiselle aika raadolliset syyt. Kasvaneiden koulutusvaatimusten taustalla on länsimaissa pelko etumatkan pienenemisestä. Etäopetuksen ja etätyön perusedellytyksenä on siirtokustannusten pienentyminen parantuneen infrastruktuurin myötä. Osa tietoammattilaisten päässä olevasta tiedosta voidaan kopioida koneen haltuun aivan kuten teollisuustyöläiset ovat menettäneen ammattitaitoaan työstökoneille ja roboteille. Rahikainen kysyy, tuleeko professorin henkilökohtaisesta opetustoiminnasta käsityöhön verrattavaa ylellisyyttä, johon vain eliitillä on varaa. Pyöriikö verkoissa vain toisarvoista tietoa, jos merkityksellinen tieto vetäytyykin piiloon säilyttääkseen markkina-arvonsa?

Rahikainen pohtii kiinnostavasti myös kehityskulkua, jossa ihmisten välillä on yhä useammin jokin kone. Modernin ihmisen autonomisuus on etäopetuksen edellytys. On aika problemaattista, jos etäopetuksen ihanteena on muista ihmisistä ja opettajasta täysin riippumaton autonominen opiskelija, joka sisäistetyn itsekurin vallassa ahertaa yksin kotonaan oppikirjojen, puhelimen ja tietokoneen ääressä sen sijaan, että avaisi oven, haistelisi vähän säätä ja lähtisi sitten kävelemään ihmisten luo. Etäopetuksesta etävalvontaan ei välttämättä ole kovin pitkää matkaa, jos halutaan maalailla kauhukuvia yhteiskunnasta, jossa vihdoinkin järjestys on voittanut kaaoksen.

Antti Kauppi pohtii oppimisen ja opettamisen haasteita myöhäismodernissa yhteiskunnassa, jossa ihmisten selviytymisstrategiat eivät enää nojaudu traditioiden kunnioitukselle ja auktoriteettien kuuliaiselle tottelemiselle. Oppimista ei saisi rajata yksilön sisäisiin prosesseihin, koska ne eivät kykene selittämään hänen suhdettaan muuttuvaan toimintaympäristöön. Tarvitaan teorianmuodostusta, jossa oppiminen jäsentyy oppijan suhteena omaan ja toimintaympäristönsä muuttumiseen. Kauppi hakee ratkaisua kontekstuaalisesta oppimiskäsityksestä. Oppimisen keskeiset haasteet näyttäytyvät sellaisina ongelmina, joihin ei ole ihan vielä löytynyt ratkaisua, mutta joissa ratkaisun raentuminen on idullaan. Tämä lähikehityksen vyöhyke on toiminnan seuraava kehitysvaihe, joka on sekä tavoittelemisen arvoinen että saavutettavissa oleva.

Oppimista ei voi erottaa kehittämistyöstä. Oppiminen on kollektiivinen tapahtuma, jossa yksilön tietoisuus rakentuu yhteisten toimintakäytäntöjen kautta. Uudenlaisen oppimisen ydin löytyy selkeimmin innovatiivisista yrityksistä ja innovatiivisten ihmisten tavasta toimia. Monimutkaiset toimintaympäristöt rakentuvat oppimisympäristöiksi. Simuloidut oppimisympäristöt, esimerkiksi tietokonepelit ovat käyttökelpoisia, varsinkin kun niitä harrastetaan yhdessä.

Antti Auer ja Juha Nieminen käsittelevät verkostoja oppimisen uutena ulottuvuutena. Heille oppimisverkosto on tavallaan strateginen suunnittelumalli. Siinä kuvataan visio, johon nykyaikaisessa aikuiskoulutuksessa tulisi pyrkiä. Oppija on aktiivinen toimija, joka itse rakentaa oman oppimisympäristönsä. Tietoverkoissa tapahtuva tietokonevälitteinen on line-opiskelu on uusi kehitysvaihe oppimisessa ja opettamisessa, joka tukee paradigman muutosta pois opettamisesta kohti keskustelua ja vuorovaikutusta. Seuraava tämän jälkeen tuleva paradigman muutos on siirtyminen verkosto-oppimiseen, verkostomaailmaan (networld). Luokkahuoneen sosiaalinen tila murtuu ja myös perinteiset opettajan ja 
oppilaan roolit murtuvat: toiminnan määrittää oppija, ei opettaja. Kirjoittajat uskovat, että tästä aiheutuu erittäin kova muutosvaade koulutusorganisaatioille, jotka tulevat lopulta pakotetuiksi muutokseen.

Kirjan lopussa Tarja Surakka ja Taina Törmä pohtivat muutoksesta aiheutuvia haasteita kansalais- ja työväenopistoille.

Maailma muuttuu - muuttuuko aikuiskoulutus? sisältää vahvan latauksen muutostietoutta ja -haastetta. Kirjan lukemisesta on varmasti hyötyä aikuiskasvatuksen ammattilaisille, jotka yrittävät pysyä mukana muutoksen tahdissa. Muutosta ihmetellessä joutuu kuitenkin myös pohtimaan joitakin asioita, olennaisimpana sitä, mikä lopulta mahtaa olla jatkuvuuden voima kaoottiseltakin vaikuttavassa muutoksessa. Onko esimerkiksi maan nykyinen yhteisvastuun hallitus sortunut menneen ajan konsteihin, joilla ei ole enää relevanssia? Opetuksen ja oppimisen alueella ollaan joka tapauksessa tekemisissä ihmisen kanssa ja jotain totta on myös vanhassa väitteessä, että ihminen ei muutu.

Kuinka vahva tekijä sivistys lopulta on ihmisessä. Onko sivistyksestä, ihmisyyden keskeisimmästä tekijästä, jatkuvasti taisteltava? Onko niinkään varmaa, että muutoksesta nousee jotain myönteistä -aina on olemassa myös rappion mahdollisuus. Tietoverkoissa voi surffailla muutenkin kuin sivistyneesti tai sivistystä tavoitellen. Tässä mielessä Seppo Niemelän esittämät ajatukset ovat tärkeitä.

Meidän suomalaisten ongelmana on, että olemme kurkottaneet sivistykseen ja korkeaan sivilisaatioon hyvin nopeasti. Traditiotietoisuutemme ei ole kehuttava ja kuitenkin juuri kulttuuriperintömme on se voimavara, jonka avulla myös muutokset voi kohdata myönteisin tuloksin. Vaaranamme on kritiikitön uuden ihailu.

Teoksen toimittajat vetoavat turistin uskallukseen, naiviuteen ja pinnallisuuteen, jolla haetaan asioita, jotka tuntuvat tärkeiltä. Hauska ja toimivakin periaate, mutta myös problemaattinen. Niinpä tekee mieli happamesti huomauttaa, että kun teos esittäytyy aikuiskoulutuksen ensimmäisenä vuosikirjana, niin Vapaan sivistystyön vuosikirjoja on sentään julkaistu jo pitkästi neljäkymmentä vuotta ja monenlaisia ajatusretkiä aikuiskoulutuksen maailmaan niissäkin on tehty.

Heikki Toivola 